\title{
Genetic gains in physic nut using selection indexes
}

\author{
Leonardo Lopes Bhering ${ }^{(1)}$, Bruno Galvêas Laviola(2), Caio Césio Salgado(1), Carlos Felipe Barrera Sanchez ${ }^{(1)}$, \\ Tatiana Barbosa Rosado(2) and Alexandre Alonso Alves(2)
}

\begin{abstract}
(1)Universidade Federal de Viçosa, Departamento de Biologia Geral, Avenida P.H. Rolfs, s/non, Campus Universitário, CEP $36570-000$ Viçosa, MG, Brazil. E-mail: leonardo.bhering@ufv.br, caiocesio@yahoo.com.br, feba286@hotmail.com (2)Embrapa Agroenergia, Parque Estação Biológica (PqEB), s/nº, CEP 70770-901 Brasília, DF, Brazil. E-mail: bruno.laviola@embrapa.br, tatianarosado@yahoo.com.br, alexandre.alonso@embrapa.br
\end{abstract}

\begin{abstract}
The objective of this work was to estimate genetic gains in physic nut (Jatropha curcas) using selection indexes and to establish the best selection strategy for the species. Direct and indirect selection was carried out using different selection indexes, totalizing 14 strategies. One hundred and seventy five families from the active germplasm bank of Embrapa Agroenergy, Brasília, Brazil, were analyzed in a randomized complete block design with two replicates. The evaluated traits were: grain yield; seeds per fruit; endosperm/ seed ratio; seed weight, length, width, and thickness; branches per plant at $0.5,1.0$, and $1.5 \mathrm{~m}$; plant height; stem diameter; canopy projection on rows and between lines; canopy volume; juvenility (days to the first flowering); and height of the first inflorescence. Evaluations were done during the second year of cultivation. The use of selection indexes is relevant to maximize the genetic gains in physic nut, favoring a better distribution of desirable traits. The multiplicative and restrictive indexes are considered the most promising for selection.

Index terms: Jatropha curcas, biodiesel, canopy volume, Cerrado, juvenility, seed size.

\section{Ganho genético em pinhão-manso com uso de índices de seleção}

Resumo - O objetivo deste trabalho foi estimar o ganho genético em pinhão-manso (Jatropha curcas) com uso de diferentes índices de seleção e estabelecer a melhor estratégia de seleção para a espécie. A seleção direta e indireta foi realizada com diferentes índices de seleção, o que totalizou 14 estratégias. Foram analisadas 175 famílias pertencentes ao banco ativo de germoplasma da Embrapa Agroenergia, em blocos ao acaso, com duas repetições. Foram avaliadas as variáveis: produtividade de grãos; sementes por fruto; razão endosperma/ semente; peso, comprimento, largura e espessura de sementes; número de ramos a 0,5,1,0 e 1,5 m; altura de plantas; diâmetro do caule; projeção da copa nas linhas e nas entrelinhas; volume da copa; juvenilidade (dias até o florescimento); e altura de inserção da primeira inflorescência. As avaliações foram realizadas durante o segundo ano de cultivo. A utilização de índices de seleção é relevante para maximizar os ganhos genéticos em pinhão-manso e favorece uma melhor distribuição de características desejáveis. Os índices multiplicativos e restritivos são considerados os mais promissores para uso na seleção.
\end{abstract}

Termos para indexação: Jatropha curcas, biodiesel, volume de copa, Cerrado, juvenilidade, tamanho de sementes.

\section{Introduction}

Jatropha curcas L., also known as physic nut, is a perennial monoecious species belonging to the Euphorbiaceae family. The species is believed to be originary from Central America, but grows spontaneously in several regions of Brazil (Rosado et al., 2010). Due to its high oil content and potential productivity, physic nut is now seen as a potential crop to meet the requirements of the Brazilian National Program for Production and Use of Biodiesel. Moreover, it is well suited for the cultivation of degraded areas and for family farming.
Recently, physic nut cultivation has been implemented in several regions of Brazil, by small, medium, and even large farmers. However, these crop fields were implemented without formal knowledge on the genotypes used, i.e., the fields are being cropped with genetically unknown plants. For this reason, information and guarantees on yield potential are nonexistent (Laviola et al., 2011). Therefore, breeding for enhanced productivity and for character fixation of physic nut genotypes is paramount, to assure this species as a viable raw material for the large-scale production of biodiesel.

Pesq. agropec. bras., Brasília, v.47, n.3, p.402-408, mar. 2012 
Genetic breeding programs of physic nut are being implemented around the world. In Brazil, a breeding program is currently held by Embrapa. This program was initiated by collecting physic nut seeds across the country. The seeds were then used to implement a large germplasm bank. Following these initial procedures, genotypes are being phenotypically and molecularly characterized. These evaluations have allowed for the acquisition of knowledge on the narrow genetic basis of physic nut in Brazil (Rosado et al., 2010; Laviola et al., 2010, 2011).

Recently, the most promising genotypes - based on initial yield evaluations - were intercrossed, and selection among and within families, as well as on the germplasm bank itself, is being carried out by Embrapa's breeding program. The election procedure used is based on the best linear unbiased prediction (Blup) for estimating genotypic genetic values, considering one trait at a time. However, in order to develop improved physic nut cultivars, breeders have to consider a number of traits simultaneously, such as productivity, plant architecture and height, among others.

In plant breeding programs, the possibility to predict genetic gains using different selection strategies is one of the main contributions of quantitative genetics. Selection strategies make it possible to more effectively orient the breeding process, to predict the result of the adopted selective scheme, and to decide, on a scientific basis, as to the breeding efficiency. The use of selection indexes is an effective strategy to obtain simultaneous gains in several traits, since it enables the combination of multiple desirable characters during selection (Cruz et al., 2004; Bhering et al., 2011).

The objective of this work was to estimate genetic gains of physic nut using different selection indexes, and to establish the best selection strategy for the species.

\section{Materials and Methods}

One hundred seventy-five families of physic nut from the active germplasm bank of Embrapa Agroenergy were evaluated in the 2009 crop year at Embrapa Cerrados, Planaltina, DF, Brazil (15³5'30"S and $47^{\circ} 42^{\prime} 30^{\prime \prime} \mathrm{W}$, at $1,007-\mathrm{m}$ altitude). According to Köppen-Geiger, the climate of the region is of the Aw type, tropical with dry winter and rainy summer. The temperature ranges from 16.4 to $28.4^{\circ} \mathrm{C}$ (average of $22^{\circ} \mathrm{C}$ ) and the relative humidity from 42.0 to $91.2 \%$ (average of $73 \%$ ). Total annual rainfall is around $1,089.4 \mathrm{~mm}$. The soil used was classified as an Oxisol with high clay content. For further information on the germplasm bank see Dias et al. (2007).

The experiment was established using a randomized complete block design with two replicates and five plants per plot, arranged in rows (4x2-m spacing). During the second crop year, phenotypic evaluations of the accessions were performed considering reproductive and vegetative traits, according to the development of the plants (Laviola et al., 2010). The evaluated traits were: grain yield $(\mathrm{g})$; weight of 100 seeds $\left(\mathrm{W}_{100}, \mathrm{~g}\right)$; number of seeds per fruit (NSF); ratio between endosperm and seed (E/S); seed length (SL, mm), width (SW, mm), and thickness (ST, mm); number of branches per plant at $0.5\left(\mathrm{TNB}_{0.5}\right), 1.0$ $\left(\mathrm{TNB}_{1.0}\right)$, and $1.5 \mathrm{~m}\left(\mathrm{TNB}_{1.5}\right)$; plant height $(\mathrm{m})$; stem diameter $(\mathrm{SD}, \mathrm{mm})$; canopy projection on the row $\left(\mathrm{CP}_{\mathrm{R}}, \mathrm{m}\right)$ and between lines $\left(\mathrm{CP}_{\mathrm{BL}}, \mathrm{m}\right)$; canopy volume $\left(\mathrm{CV}, \mathrm{m}^{3}\right)$; juvenility, measured as the number of days to the first flowering (NDF, days); and height of the first inflorescence (HFI, m). Canopy volume was estimated by the approximation of the volume of a cylinder, with elliptical base, using the formula described by Laviola et al. (2010). The evaluations were done from November 2009 to July 2010.

The statistical model used considered the complete randomized block design, with information within the plots, as (Cruz, 2006): $\mathrm{Y}_{\mathrm{ijk}}=\mu+\mathrm{g}_{\mathrm{i}}+\mathrm{b}_{\mathrm{j}}+\varepsilon_{\mathrm{ij}}+\delta_{\mathrm{ijk}}$, in which $\mathrm{Y}_{\mathrm{ijk}}$ is the observation of the $\mathrm{k}^{\text {th }}$ individual, evaluated in the $i^{\text {th }}$ genotype of the $\mathrm{j}^{\text {th }}$ replicate; $\mu$ is the overall mean of the experiment; $g_{i}$ is the effect of genotype $i ; b_{j}$ is the effect of block $j ; \varepsilon_{i j}$ is the effect of plot $\mathrm{ij}$; and $\delta_{\mathrm{ijk}}$ is the effect of the $\mathrm{k}$ individual, of the $\mathrm{i}^{\text {th }}$ genotype on the $\mathrm{j}^{\text {th }}$ block.

The genotypic and phenotypic correlations were estimated between the 17 evaluated traits. In addition, based on the phenotypic and genotypic covariance matrices, prediction of genetic gains was done using different methodologies. To calculate the predicted genetic gain, the following estimator was used: $\mathrm{SG}=\mathrm{h}^{2} \times \mathrm{SD}$, in which $\mathrm{SG}$ is the selection gain; $h^{2}$ is the heritability of the trait; and SD is the selection differential, obtained by the average of the selected individuals minus the average of the original population. 
For the estimation of direct and indirect selection effects, six variables with greater relevance to the breeding program were selected. The following eight methodologies were used for gain estimation: classic index proposed by Smith (1936) and Hazel (1943); sum of ranks index (Mulamba \& Mock, 1978); base index (Williams, 1962); multiplicative index (Subandi et al., 1973); free weights and parameters index (Elston, 1963); index based on desired gains (Pesek \& Baker, 1969); restricted index (Kempthorne \& Nordskog, 1959); and genotype-ideotype distance index (Cruz, 2006). Generally, a linear index can be represented by $\mathrm{I}=\mathrm{b} 1 \times 1+\mathrm{b} 2 \times 2+\ldots+\mathrm{bnXn}$, in which: I is the selection index obtained through the simultaneous analysis of $\mathrm{n}$ variables; and $\mathrm{b}$ is the $\mathrm{n} \times 1$ vector dimension of the weightings of the index to be estimated, i.e., the average of $\mathrm{n}$ variables.

To predict the genetic gains, a selection intensity of $20 \%$ of the families was used, i.e., from the 175 evaluated families, the best 35 were selected by the different methodologies adopted.

\section{Results and Discussion}

A significant difference was observed for 13 of the 17 evaluated variables (Table 1). Since significant variability between families is essential for genetic progress, the variables $\mathrm{NSF}, \mathrm{E} / \mathrm{S}, \mathrm{TNB}_{0.5}$, and $\mathrm{TNB}_{1.0}$ were not used in the estimations of genetic gain. The estimated genetic variability for the components of production, in the present study, does not agree with the low genetic diversity quantified using molecular markers on the physic nut collection worldwide (Achten et al., 2010; Rosado et al., 2010). This may be related to a possible dissociation of the neutral molecular markers used in these studies with the genes that control production traits. Studies on morphological traits related to production have highlighted the existence of genetic diversity in physic nut in Brazil and worldwide. Ginwal et al. (2004) detected genetic variability of physic nut as to seed morphology, germination, growth traits, and oil yield. In Brazil, Abreu et al. (2009) found significant genetic variability between ten accessions evaluated in the state of Mato Grosso do Sul as to four morphological traits. Laviola et al. $(2010,2011)$ also reported the existence of genetic variability in physic nut as to different traits related to production, measured in young plants.

The value of the observed phenotypic correlation ranged from 0.4089 , between $\mathrm{TNB}_{1.0}$ and $\mathrm{NDF}$, to 0.985 , between HFI and E/S (Table 2). Genetic correlations showed a similar trend to the phenotypic ones. Similar results were observed in young (Laviola et al., 2010) and adult (Spinelli et al., 2010) plants. Genotypic correlation values may be used to guide genetic breeding programs, if they reflect the fraction of the phenotypic expression of the two traits of co-heritable nature

Table 1. Synthesis of the analysis of variance of 175 families of Jatropha curcas, and estimations of genetic and phenotypic parameters of the variables: grain yield (g), weight of 100 seeds $\left(\mathrm{W}_{100}, \mathrm{~g}\right)$, number of seeds per fruit (NSF), ratio between endosperm and seed (E/S), seed length (SL, mm), seed width (SW, mm), seed thickness (ST, mm), total number of branches per plant at $0.5 \mathrm{~m}\left(\mathrm{TNB}_{0.5}\right), 1.0 \mathrm{~m}\left(\mathrm{TNB}_{1.0}\right)$, and $1.5 \mathrm{~m}\left(\mathrm{TNB}_{1.5}\right)$, plant height $(\mathrm{m})$, stem diameter $(\mathrm{SD}, \mathrm{mm})$, canopy projection on the row $\left(\mathrm{CP}_{\mathrm{R}}, \mathrm{m}\right)$ and between lines $\left(\mathrm{CP}_{\mathrm{BL}}, \mathrm{m}\right)$, canopy volume $\left(\mathrm{CV}, \mathrm{m}^{3}\right)$, number of days to the first flowering (NDF, days), and height of the first inflorescence (HFI, $\mathrm{m})^{(1)}$.

\begin{tabular}{|c|c|c|c|c|c|c|c|c|c|c|c|c|c|c|c|c|c|c|}
\hline \multirow{2}{*}{$\begin{array}{l}\text { Source of } \\
\text { variation }\end{array}$} & \multirow[t]{2}{*}{$\mathrm{DF}$} & \multicolumn{17}{|c|}{ Mean squares } \\
\hline & & Yield & $\mathrm{W}_{100}$ & NSF & $\mathrm{E} / \mathrm{S}$ & SL & SW & ST & $\mathrm{TNB}_{0.5}$ & $\mathrm{TNB}_{1.0}$ & $\mathrm{TNB}_{1.5}$ & Height & SD & $\mathrm{CP}_{\mathrm{R}}$ & $\mathrm{CP}_{\mathrm{BL}}$ & $\mathrm{CV}$ & $\mathrm{NDF}$ & HFI \\
\hline Blocks & 1 & $739,616.80$ & 6.40 & 1.19 & 0.01 & 3.17 & 0.03 & 0.191 & 133.70 & 320.70 & 890.00 & 0.15 & 1351.80 & 1.75 & 1.90 & 27.25 & $32,027.90$ & 0.01 \\
\hline Genotypes & 174 & $35,277.7^{* *}$ & $139.90 * *$ & $0.05^{\mathrm{ns}}$ & $0.00^{\mathrm{ns}}$ & $1.30 * *$ & $0.53 * *$ & $0.62 * *$ & $2.70^{\text {ns }}$ & $4.50^{\mathrm{ns}}$ & $15.10^{* *}$ & $0.16^{* *}$ & $555.20 * *$ & $0.21 * *$ & $0.29 * *$ & $6.41 * *$ & $742.90 * *$ & $0.04 * *$ \\
\hline Between & 174 & $13,143.70$ & 62.70 & 0.04 & 0.00 & 0.52 & 0.21 & 0.22 & 2.70 & 3.90 & 9.50 & 0.07 & 280.50 & 0.09 & 0.13 & 2.36 & 354.90 & 0.02 \\
\hline Within & 1213 & $4,490.30$ & 15.90 & 0.03 & 0.00 & 0.27 & 0.05 & 0.07 & 1.40 & 2.00 & 4.50 & 0.02 & 149.10 & 0.06 & 0.07 & 1.14 & 185.10 & 0.01 \\
\hline Means & & 182.60 & 65.00 & 2.70 & 0.61 & 17.68 & 10.69 & 8.40 & 4.49 & 5.22 & 7.08 & 2.43 & 120.67 & 1.20 & 1.29 & 3.10 & 141.55 & 1.15 \\
\hline$\sigma_{\mathrm{G}}^{2}$ between & & $2,719.80$ & 9.50 & 0.00 & 0.00 & 0.10 & 0.04 & 0.05 & 0.01 & 0.08 & 0.68 & 0.01 & 33.75 & 0.01 & 0.02 & 0.50 & 47.67 & 0.00 \\
\hline$\sigma_{\mathrm{G}}^{2}$ within & & $1,359.90$ & 4.70 & 0.00 & 0.00 & 0.05 & 0.02 & 0.02 & 0.00 & 0.04 & 0.34 & 0.01 & 16.87 & 0.01 & 0.01 & 0.25 & 23.83 & 0.00 \\
\hline$\sigma_{\text {p between }}^{2}$ & & $4,490.30$ & 15.90 & 0.03 & 0.00 & 0.27 & 0.05 & 0.07 & 1.40 & 2.00 & 4.52 & 0.02 & 149.09 & 0.06 & 0.07 & 1.14 & 185.12 & 0.01 \\
\hline $\mathrm{h}^{2}$ & & 62.70 & 55.20 & 16.50 & 16.94 & 59.94 & 59.85 & 64.91 & 2.23 & 13.67 & 36.86 & 60.25 & 49.48 & 55.94 & 54.57 & 63.18 & 52.22 & 46.77 \\
\hline $\mathrm{CV}_{\exp }$ & & 25.20 & 5.20 & 3.70 & 1.70 & 1.40 & 1.80 & 2.20 & 12.39 & 13.01 & 15.67 & 4.10 & 4.70 & 7.70 & 9.70 & 17.60 & 4.50 & 4.40 \\
\hline $\mathrm{CV}_{\mathrm{g}} / \mathrm{CV}_{\mathrm{e}}$ & & 1.10 & 0.90 & 0.70 & 0.85 & 1.70 & 0.98 & 1.18 & 1.90 & 0.40 & 0.74 & 1.10 & 1.00 & 1.29 & 1.10 & 1.29 & 1.06 & 0.99 \\
\hline
\end{tabular}

${ }^{(1)} \sigma_{\mathrm{G}}^{2}$, genetic variance; $\sigma_{\mathrm{P}}^{2}$, phenotypic variance; $\mathrm{h}^{2}$, heritability; $\mathrm{CV}_{\mathrm{exp}}$, coefficient of experimental variation; $\mathrm{CV}_{\mathrm{g}} / \mathrm{CV}_{\mathrm{e}}$, ratio between coefficient of genetic variation and coefficient of environmental variation. ${ }^{\mathrm{ns}}$ Nonsignificant.** Significant at $1 \%$ probability. 
(Resende, 2002). Therefore, the selection on trait "x" may foster alterations on trait "y". For example, in order to obtain truly superior genetic material, it is necessary for a series of favorable attributes to be simultaneously present in the selected material, in order to ensure great yields and customer satisfaction as to quality demands (Cruz et al., 2004; Bhering et al., 2011). Knowledge on genotypic correlations between physic nut traits is especially important on the definition of selection criterion for economically important traits and for the construction of multi-trait selection indexes (Bhering et al., 2011).

Grain yield showed a positive correlation of mid to high magnitude with the character traits $\mathrm{CV}, \mathrm{CP}_{\mathrm{BL}}, \mathrm{CP}_{\mathrm{R}}$, and $\mathrm{TNB}_{1.5}$ (Table 2), indicating that direct selection for grain yield will also increase canopy volume and diameter. This information is relevant to predict canopy architecture of cultivars and the necessary adjustments in the production system (i.e. adjusting harvesting machine size and capacity).

However, the variables yield and $\mathrm{W}_{100}$ showed negative and low magnitude correlations, indicating a tendency of the more productive plants to produce smaller and lighter grains. Moreover, there are reports of positive correlation between grain weight and oil yield (Ginwal et al., 2004; Kaushik et al., 2007; Rao et al., 2008; Spinelli et al., 2010), which, if confirmed, can lead to reduced oil content after several selecting cycles for grain yield. Therefore, the use of selection indexes is important to avoid significant reduction in $\mathrm{W}_{100}$ due to genetic breeding for grain yield.

Based on the results of the analysis of variance and correlation, and considering the traits of greater interest to breeding, six variables were selected for gain prediction by the different methodologies adopted for direct and indirect selection, with the use of selection indexes (Table 3). The prediction gains, by applying a selection intensity of $20 \%$, varied from 3.05 to $81.43 \%$, indicating the importance of selecting the best methodology to obtain greater gains. Based on direct selection for yield, a total gain of $74.2 \%$ was obtained, of which $36.9 \%$ was represented by gains in yield. However, using this strategy, there was no gain in $\mathrm{W}_{100}$; in fact, a slight tendency of reducing grain weight was observed, which could lead to the indirect reduction of oil content over several selection cycles. For the remaining traits, the gain was positive: around $18 \%$ for canopy volume and approximately $6 \%$ for the other traits.

Table 2. Phenotypic correlations (above the diagonal) and genetic correlation (below the diagonal), in the analysis of 175 families of Jatropha curcas, between the evaluated traits: grain yield (yield), weight of 100 seeds $\left(\mathrm{W}_{100}\right)$, number of seeds per fruit (NSF), ratio between endosperm and seed (E/S), seed length (SL), seed width (SW), seed thickness (ST), total number of branches at $0.5 \mathrm{~m}\left(\mathrm{TNB}_{0.5}\right), 1.0 \mathrm{~m}\left(\mathrm{TNB}_{1.0}\right)$, and $1.5 \mathrm{~m}\left(\mathrm{TNB}_{1.5}\right)$, height, stem diameter $(\mathrm{SD})$, canopy projection on the row $\left(\mathrm{CP}_{\mathrm{R}}\right)$ and between lines $\left(\mathrm{CP}_{\mathrm{BL}}\right)$, canopy volume $(\mathrm{CV})$, number of days to the first flowering $(\mathrm{NDF})$, and height of the first inflorescence (HFI).

\begin{tabular}{|c|c|c|c|c|c|c|c|c|c|c|c|c|c|c|c|c|c|}
\hline $\mathrm{r}$ & ield & $N_{100}$ & SF & S & SL & $\mathrm{W}$ & $\mathrm{T}$ & $\mathrm{TNB}_{0.5}$ & $\mathrm{TNB}_{1,0}$ & $\mathrm{TNB}_{1.5}$ & Height & SD & $\mathrm{CP}_{\mathrm{R}}$ & $1 \mathrm{BL}$ & - & NDF & HFI \\
\hline eld & 1 & -0.122 & $0.1533^{*}$ & 0.1067 & $-0.2061 * *$ & 0.0032 & -0.08 & $0.1789 *$ & $0.2191 * *$ & $0.3917^{* *}$ & $* *$ & 0.309 & $0.4709 * *$ & 0.515 & $5583 * *$ & ${ }^{*}-0.0404$ & 5 \\
\hline$V_{100}$ & 3 & 1 & 101 & $655^{* *}$ & $0.6741 *$ & 0.485 & $2 * *$ & 0 & 42 & 87 & 49 & 09 & $7 * *$ & 0 & 35 & 61 & $* *$ \\
\hline SF & 3171 & 2159 & 1 & 168 & $* 0.20$ & 0. & & 0.0938 & & & & 39 & & & $0.1665^{*}$ & $0.3566^{* *}$ & $* *$ \\
\hline S & 2637 & 4179 & .9012 & 1 & 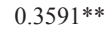 & & & 0.0584 & -0.26 & $-0.2092 * *$ & & $0.167 *$ & & & & & \\
\hline 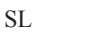 & 6 & 41 & 05 & 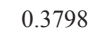 & 1 & $0.598 * *$ & $0.6765 * *$ & 0.0499 & 0.0105 & -0.1038 & & 504 & & & & 0.0822 & $5 * *$ \\
\hline & & 6693 & & & & t & & & & & & & & & & & \\
\hline & .1133 & 8079 & 0.280 & & 647 & 0.0071 & 1 & .1251 & 0.0100 & -0.0882 & $0.3158 * *$ & 0.0712 & $0.2385 * *$ & 0.1 & 0.1208 & $0.2148^{* *}$ & * $0.4242 * *$ \\
\hline $\mathrm{NB}_{0.5}$ & 3656 & 0.5896 & 0.4856 & 8192 & -0.0917 & .9524 & 0.4422 & 1 & $6948 * *$ & $0.3201 * *$ & 0.0246 & $0.2903^{* *}$ & 0.1364 & $0.2192 * *$ & $0.1737 *$ & -0.0511 & 0.0439 \\
\hline $\mathrm{NB}_{1.0}$ & 225 & 0.2461 & -0.4652 & -0.7836 & -0.1231 & -0.0741 & -0.1418 & -0.2384 & 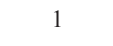 & $0.5967^{* *}$ & $-0.2336^{* *}$ & $0.1569 *$ & 0.1423 & 0.1 & $13 * *$ & ${ }^{*}-0.4089^{* *}$ & $71^{* *}$ \\
\hline $\mathrm{NB}_{1.5}$ & 3705 & -0.0717 & -0.3655 & -0.2962 & -0.3066 & -0.0669 & -0.2282 & 0.4201 & 0.1139 & ( & -0.005 & $0.361^{* *}$ & $84 * *$ & 0 & 0 . & -0 & $*-0$ \\
\hline eight & 3375 & 0.2043 & 0.8056 & 0.8455 & 0.1269 & .5865 & 56 & 0.3223 & -0.8625 & -0.0288 & 1 & $0.4622 * *$ & $0.5847 * *$ & 0.5 & $0.5106^{* *}$ & 0.40 & * $0.7935^{* *}$ \\
\hline 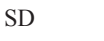 & 314 & .0717 & 0.2245 & 0.4305 & -0.1378 & .3684 & 19 & 0.6013 & -0.3698 & 0.3179 & 6816 & 1 & $0.4231 * *$ & $0.4487 * *$ & $0.4686^{* *}$ & * $\quad 0.1272$ & $0.1714^{*}$ \\
\hline$P_{R}$ & 5517 & 0.4212 & 0.4358 & 0.492 & 0.0915 & & & -0.5105 & -0.1401 & & & 550 & 1 & 0.861 & $9 * *$ & & $48 * *$ \\
\hline $\mathrm{P}_{\mathrm{BL}}$ & 0.5837 & 0.4139 & 0.2944 & 0.4824 & 0.112 & 0.2983 & 383 & 0.2075 & -0.0458 & & 399 & 30 & 614 & t & $0.9318^{* *}$ & * 0.0474 & $0.4255^{* *}$ \\
\hline $\mathrm{CV}$ & 0.5739 & 0.2903 & 0.2935 & 0.3417 & 0.0092 & 0.227 & 1591 & -0.002 & 0.1461 & 0.7227 & & 0.5227 & 0.9845 & 0.9732 & t & -0.0737 & $0.2375^{* *}$ \\
\hline NDF & 0.1621 & -0.1217 & 0.4314 & 0.4573 & 0.0394 & 0.4223 & 0.2975 & 0.0041 & -0.3268 & -0.0269 & 0.6161 & 0.6352 & 0.1453 & 0.2361 & 0.0935 & 1 & $0.4924 * *$ \\
\hline IFI & 0.3038 & 0.3762 & 0.8959 & 0.9952 & 0.357 & 0.5987 & 0.5001 & 0.4356 & -0.8837 & -0.3137 & 0.8891 & 0.4491 & 0.4755 & 0.4774 & 0.3491 & 0.5249 & 1 \\
\hline
\end{tabular}

$*$ and $* *$ Significant at 5 and $1 \%$ probability by the $\mathrm{t}$ test, respectively. 
As expected, direct selection for $\mathrm{W}_{100}$ did not foster gains in grain yield, which showed a decrease of $4.24 \%$. Total gain with direct selection on $\mathrm{W}_{100}$ was only of $3.05 \%$, which was the lowest predicted gain considering the different traits and methodologies. To increase the gains in $\mathrm{W}_{100}$, it is necessary to apply lower selection intensities or to introduce variability in the breeding population.

Considering direct selection based only on one trait and indirect gain on the remaining variables, the selection for $\mathrm{CV}$ provided the greatest predicted gain $(76.03 \%)$. However, in this case, the indirect gain in grain yield was only of $19.73 \%$. Therefore, despite providing better gains, the direct selection for $\mathrm{CV}$ would not be an adequate strategy for breeding programs that aim to select plants with high grain and oil productivity.

The classic index proposed by Smith (1936) and Hazel (1943) consists in a linear combination of several traits of economic importance. For the elaboration of this index, coefficients of genetic variation for each trait were used as economic weights, according to Cruz (1990). The total gain predicted by this methodology was of $69.46 \%$, and the total and indirect gains for all traits were inferior to the one obtained by direct selection in yield. Therefore, the adoption of this index is not interesting for breeding programs.

The selection index of Mulamba \& Mock (1978) involves ranking the evaluated genotypes in an order that is favorable to breeding, according to each trait. Once ranked, the orders of each genotype are added, resulting in an additional measurement (sum of ranks). This index has been suggested for several crops, such as popcorn (Santos et al., 2007; Freitas Júnior et al., 2009), passion fruit (Gonçalves et al., 2007), and potato (Barbosa \& Pinto, 1998). In the present work, the methodology provided a gain of $76.05 \%$, the third best result using indexes. It should be noted that none of the traits showed a negative gain, which is also interesting, considering the objective is to obtain elevated gains for all the assessed variables.

The base index (Williams, 1962) does not require the use of genotypic and phenotypic variance and covariance matrixes - which can be imprecise -, and uses only economic weights to compose the index, with linear combinations of average phenotypic values. In the present study, the adoption of this index provided a total predicted gain of $74.2 \%$, and the estimated values for all traits were equal to the direct selection for grain yield. The coefficient of genetic variation was used as an economic weight, as proposed by Smith (1936) and Hazel (1943).

The methodology proposed by Subandi et al. (1973), known as the multiplicative index, enabled the greatest gains. According to this methodology, it is not necessary to establish an economic weight or to use a phenotypic and genotypic covariance matrix. This index causes the distribution of gains throughout the variables, increasing total gain (81.43\%). Moraes Neto (2006a, 2006b, 2008), while evaluating Pinus, identified this index as the best alternative for selection, as it enabled

Table 3. Predicted selection gains (\%) for the different strategies adopted, considering the six traits of interest: yield, weight of 100 seeds $\left(\mathrm{W}_{100}\right)$, total number of branches $\left(\mathrm{TNB}_{1.5}\right)$, canopy projection on the row $\left(\mathrm{CP}_{\mathrm{R}}\right)$, canopy projection between lines $\left(\mathrm{CP}_{\mathrm{BL}}\right)$, and canopy volume $(\mathrm{CV})$.

\begin{tabular}{|c|c|c|c|c|c|c|c|}
\hline Strategy & Yield & $\mathrm{W}_{100}$ & $\mathrm{TNB}_{1.5}$ & $\mathrm{CP}_{\mathrm{R}}$ & $\mathrm{CP}_{\mathrm{BL}}$ & $\mathrm{CV}$ & Total $(\%)$ \\
\hline Direct and indirect selection for yield & 36.9 & -0.12 & 5.46 & 6.54 & 7.35 & 18.07 & 74.20 \\
\hline Direct and indirect selection for $\mathrm{W}_{100}$ & -4.24 & 4.29 & -1.71 & 1.02 & 1.02 & 2.67 & 3.05 \\
\hline Direct and indirect selection for $\mathrm{TNB}_{1.5}$ & 13.88 & -0.47 & 11.03 & 7.6 & 7.84 & 17.56 & 57.44 \\
\hline Direct and indirect selection for $\mathrm{CP}_{\mathrm{R}}$ & 15.51 & 1.09 & 5.02 & 11.14 & 9.4 & 25.93 & 68.09 \\
\hline Direct and indirect selection for $\mathrm{CP}_{\mathrm{BL}}$ & 19.74 & 0.29 & 6.57 & 9.33 & 11.39 & 26.38 & 73.70 \\
\hline Direct and indirect selection for $\mathrm{CV}$ & 19.73 & 0.92 & 6.28 & 10.79 & 10.73 & 27.58 & 76.03 \\
\hline Classic index & 36.27 & -0.33 & 3.65 & 5.88 & 6.98 & 17.01 & 69.46 \\
\hline Sum of ranks index & 20.9 & 1.33 & 7.9 & 9.9 & 10.56 & 25.46 & 76.05 \\
\hline Base index & 36.9 & -0.12 & 5.46 & 6.54 & 7.35 & 18.07 & 74.20 \\
\hline Multiplicative index & 26.24 & 0.59 & 6.95 & 9.97 & 10.96 & 26.72 & 81.43 \\
\hline Index free of weights and parameters & 21.14 & 1.9 & 8.36 & 8.57 & 9.6 & 23.19 & 72.76 \\
\hline Index based on desired gains & 13.02 & 1.87 & 3.76 & -0.3 & -1.17 & -0.17 & 17.00 \\
\hline Restricted index & 31.88 & 0 & 4.14 & 6.69 & 7.68 & 17.09 & 67.47 \\
\hline Genotype-ideotype distance & 23.64 & 0.53 & 7.8 & 10.02 & 10.85 & 26.37 & 79.21 \\
\hline
\end{tabular}

Pesq. agropec. bras., Brasília, v.47, n.3, p.402-408, mar. 2012 
a greater total gain and a greater balance in the gains of improving traits.

Another tested methodology was the index free of weights and parameters (Elston, 1963). Similarly to the multiplicative index, this methodology does not require a phenotypic and genotypic covariance matrix or weight establishment. Despite the advantages of this method, total predicted gain was inferior to the ones observed for the previous methodologies. It is important to highlight that this index showed the greatest gain for the $\mathrm{W}_{100}$ trait, except for direct selection. Therefore, this index seems to be promising to increase the gains in this trait, without major losses in others.

The index proposed by Pesek \& Baker (1969) uses desired gains for each trait as values equivalent to the standard deviation (Crosbie et al., 1980; Vieira, 1988). The index provided gains of only $17 \%$, the lowest value of all selection index strategies evaluated. It is worth mentioning that, using this index, traits related to grain yield, such as $\mathrm{CP}_{\mathrm{R}}, \mathrm{CP}_{\mathrm{BL}}$, and $\mathrm{CV}$, showed negative gains. These unsatisfactory results confirm those obtained by Suwantaradon et al. (1975), Kauffmann \& Dudley (1979), and Crosbie et al. (1980).

When the restricted index (Kempthorne \& Nordskog, 1959) was used, the restriction was assigned to the variable $\mathrm{W}_{100}$, so as not to allow negative gains due to its negative correlation with grain yield. Besides this restriction, the coefficient of genetic variation was adopted as the economic weight to form the index. The prediction of total genetic gain by this index was $67.47 \%$, lower than the ones of the other methodologies. However, the restricted index provided the largest gain in grain yield (31.88\%), without negative impact in grain weight. Considering the positive correlation between grain weight and oil content (Ginwal et al., 2004; Kaushik et al., 2007; Rao et al., 2008; Spinelli et al., 2010), this methodology can be an interesting option to improve grain yield without affecting other production components.

The genotype-ideotype distance methodology (Cruz, 2006) provided gains of $79.21 \%$, lower only than the one provided by the multiplicative index. The gains were well distributed among the variables, showing that the methodology has the potential to be used in physic nut breeding programs. Moraes Neto \& Melo (2006a, 2006b) reported satisfactory results using this index for Pinus caribaea, indicating its potential usefulness for selection in perennial species.

\section{Conclusions}

1. The use of selection indexes can provide balanced gains for numerous traits of interest in physic nut.

2. These indexes can guarantee long-term gains in grain productivity, without jeopardizing genetic gains in order traits.

3. Among the evaluated indexes, the ones with best results for physic nut selection are the multiplicative index and the restrictive index.

\section{References}

ABREU, F.B.; RESENDE, M.D.V. de; ANSELMO, J.L.; SATURNINO, H.M.; BRENHA, J.A.M.; FREITAS, F.B. de. Variabilidade genética entre acessos de pinhão-manso na fase juvenil. Magistra, v.21, p.36-40, 2009.

ACHTEN, W.M.J.; NIELSEN, L.R.; AERTS, R.; LENGKEEK, A.G.; KJAER, E.D.; TRABUCCO, A.; HANSEN, J.K.; MAES, W.H.; GRAUDAL, L.; AKINNIFESI, F.K.; MUYS, B. Towards domestication of Jatropha curcas. Biofuels, v.1, p.91-107, 2010.

BARBOSA, M.H.P.; PINTO, C.A.B.P. Eficiência de índices de seleção na identificação de clones superiores de batata. Pesquisa Agropecuária Brasileira, v.33, p.149-156, 1998.

BHERING, L.L.; CRUZ, C.D.; LAVIOLA, B.G. Biometria aplicada ao melhoramento de espécies alternativas para a produção de biodiesel. In: CARDOSO, D.L.; LUZ, L.N. da; PEREIRA, T.N.S. (Ed.). Estratégias em melhoramento de plantas. Viçosa: Arka, 2011. p.90-129.

CROSBIE, T.M.; MOCK, J.J.; SMITH, D.S. Comparison of gains predicted by several selection methods for cold tolerance traits of two maize populations. Crop Science, v.20, p.649-655, 1980.

CRUZ, C.D. Aplicação de algumas técnicas multivariadas no melhoramento de plantas. 1990. 188p. Tese (Doutorado) - Escola Superior de Agricultura Luiz de Queiroz, Piracicaba.

CRUZ, C.D. Programa Genes: biometria. Viçosa: UFV, 2006. 382 p.

CRUZ, C.D.; REGAZZI, A.J.; CARNEIRO, P.C.S. Modelos biométricos aplicados ao melhoramento genético. 3.ed. Viçosa: UFV, 2004. v.2, 480p.

DIAS, L.A. dos S.; LEME, L.P.; LAVIOLA, B.G.; PALLINI FILHO, A.; PEREIRA, O.L.; DIAS, D.C.F.S.; CARVALHO, M.; MANFIO, C.E.; SANTOS, A.S. dos; SOUSA, L.C.A. de; OLIVEIRA, T.S. de; PRETTI, L.A. Cultivo de pinhão-manso (Jatropha curcas L.) para produção de óleo combustível. Viçosa: L.A.S. Dias, 2007. 40p.

ELSTON, R.C. A weight-free index for the purpose of ranking or selection with respect to several traits at a time. Biometrics, v.19, p.85-97, 1963.

FREITAS JÚNIOR, S. de P.; AMARAL JÚNIOR, A.T. do; RANGEL, R.M.; VIANA, A.P. Predição de ganhos genéticos na população de milho pipoca UNB-2U sob seleção recorrente 
utilizando-se diferentes índices de seleção. Semina: Ciências Agrárias, v.30, p.803-814, 2009.

GINWAL, H.S.; RAWAT, P.S.; SRIVASTAVA, R.L. Seed source variation in growth performance and oil yield of Jatropha curcas Linn. in Central India. Silvae Genetica, v.53, p.186-192, 2004.

GONÇALVES, G.M.; VIANA, A.P.; BEZERRA NETO, F.V.; PEREIRA M.G.; PEREIRA, T.N.S. Seleção e herdabilidade na predição de ganhos genéticos em maracujá-amarelo. Pesquisa Agropecuária Brasileira, v.42, p.193-198, 2007.

HAZEL, L.N. The genetic basis for constructing selection indexes. Genetics, v.28, p.476-490, 1943.

KAUFFMAN, K.D.; DUDLEY, J.W. Selection indices corn grain-yield, percent protein, and kernel weight. Crop Science, v.19, p.538-583, 1979.

KAUSHIK, N.; KUMAR, K.; KUMAR, S.; KAUSHIK, N.; ROY, $\mathrm{S}$. Genetic variability and divergence studies in seed traits and oil content of Jatropha (Jatropha curcas L.) accessions. Biomass and Bionergy, v.31, p.497-502, 2007.

KEMPTHORNE, O.; NORDSKOG, A.W. Restricted selection indices. Biometrics, v.15, p.10-19, 1959.

LAVIOLA, B.G.; BHERING, L.L.; MENDONÇA, S.; ROSADO, T.B.; ALBRECHT, J.C. Caracterização morfo-agronômica do banco de germoplasma de pinhão-manso na fase jovem. Bioscience Journal, v.27, p.371-379, 2011.

LAVIOLA, B.G.; ROSADO, T.B.; BHERING, L.L.; KOBAYASHI, A.K.; RESENDE, M.D.V. de. Genetic parameters and variability in physic nut accessions during early developmental stages. Pesquisa Agropecuária Brasileira, v.45, p.1117-1123, 2010.

MORAES NETO, S.P. de. Comparação entre dois métodos de seleção para Pinus oocarpa. In: SIMPÓSIO NACIONAL CERRADO, 9.; SIMPÓSIO INTERNACIONAL SAVANAS TROPICAIS, 2., 2008, Brasília. Desafios e estratégias para o equilíbrio entre sociedade, agronegócio e recursos naturais: anais. Planaltina: Embrapa Cerrados, 2008. p.1-7.

MORAES NETO, S.P. de; MELO, J.T. de. Índices de seleção para famílias de meio-irmãos de Pinus caribaea var. hondurensis. Planaltina: Embrapa Cerrados, 2006a. 23p. (Embrapa Cerrados. Boletim de pesquisa e desenvolvimento, 174).

MORAES NETO, S.P. de; MELO, J.T. de. Índices de seleção para famílias de meio-irmãos de Pinus tecunumanii. Planaltina: Embrapa Cerrados, 2006b. 23p. (Embrapa Cerrados. Boletim de pesquisa e desenvolvimento, 173).
MULAMBA, N.N.; MOCK, J.J. Improvement of yield potential of the Eto Blanco maize (Zea mays L.) population by breeding for plant traits. Egyptian Journal of Genetics and Cytology, v.7, p.40-51, 1978 .

PESEK, J.; BAKER, R.J. Desired improvement in relation to selection indices. Canadian Journal of Plant Science, v.49, p.803-804, 1969.

RAO, G.R.; KORWAR, G.R.; SHANKER,A.K.; RAMAKRISHNA, Y.S. Genetic associations, variability and diversity in seed traits, growth, reproductive phenology and yield in Jatropha curcas L. accessions. Trees, v.22, p.697-709, 2008.

RESENDE, M.D.V. de. Genética biométrica e estatística no melhoramento de plantas perenes. Brasília: Embrapa Informação Tecnológica; Colombo: Embrapa Florestas, 2002. 975p.

ROSADO, T.B.; LAVIOLA, B.G.; FARIA, D.A.; PAPPAS, M.R.; BHERING, L.L.; QUIRINO, B.; GRATTAPAGLIA, D. Molecular markers reveal limited genetic diversity in a large germplasm collection of the biofuel crop Jatropha curcas L. in Brazil. Crop Science, v.50, p.2372-2382, 2010.

SANTOS, F.S.; AMARAL JÚNIOR, A.T. do; FREITAS JÚNIOR, S. de P.; RANGEL, R.M.; PEREIRA, M.G. Predição de ganhos genéticos por índices de seleção na população de milho-pipoca Unb-2u sob seleção recorrente. Bragantia, v.66, p.389-396, 2007.

SMITH, H.F. A discriminant function for plant selection. Annals of Human Genetics, v.7, p.240-250, 1936.

SPINELLI, V.M.; ROCHA, R.B.; RAMALHO, A.R.; MARCOLAN, A.L.; VIEIRA, J.R.; FERNANDES, C. de F.; MILITAO, J.S.T.; DIAS, L.A. dos S. Componentes primários e secundários do rendimento de óleo de pinhão-manso. Ciência Rural, v.40, p.1752-1758, 2010.

SUBANDI, W.; COMPTON, A.; EMPIG, L.T. Comparison of the efficiencies of selection indices for three traits in two variety crosses of corn. Crop Science, v.13, p.184-186, 1973.

SUWANTARADON, K.; EBERHART, S.A.; MOCK, J.J.; OWENS, J.C.; GUTHRIE, W.D. Index selection for several agronomic traits in the BSSS2 maize population. Crop Science, v. 15, p.827-833, 1975 .

VIEIRA, J.V. Herdabilidade, correlações e índice de seleção em populações de cenoura (Daucus carota L.). 1988. 86p. Tese (Doutorado) - Universidade Federal de Viçosa, Viçosa.

WILLIAMS, J.S. The evaluation of a selection index. Biometrics, v.18, p.375-393, 1962.

Received on April 10, 2011 and accepted on February 29, 2012

Pesq. agropec. bras., Brasília, v.47, n.3, p.402-408, mar. 2012 